\title{
Characterization and Cytoskeletal Association of a Major Cell Surface Glycoprotein, GP 140, in Human Neutrophils
}

\author{
Suzanne J. Suchard and Laurence A. Boxer \\ Department of Pediatrics, Section of Hematology/Oncology, University of Michigan School of Medicine, Ann Arbor, Michigan 48109
}

\section{Abstract}

The binding of specific ligands to neutrophil cell surface receptors and the association of these receptors with the cytoskeleton may represent an essential step in activation. To identify surface proteins that are linked to the cytoskeleton during activation, neutrophil ${ }^{125} \mathrm{I}$-surface labeled plasma membranes were extracted with Triton $X-100$, and the soluble and insoluble (cytoskeleton) fractions analyzed by SDS-PAGE and autoradiography. The major cell surface proteins recruited to the cytoskeleton after activation with Con A, FMLP, zymosan-activated serum, or immune complexes possessed a relative molecular mass in the range of 80 to $13 \mathrm{kD}$. In addition to these proteins, WGA stimulates the recruitment of a $140-\mathrm{kD}$ protein (GP 140) to the cytoskeletal fraction. That GP 140 is a WGA-binding protein was verified by Western blotting and WGA-Sepharose affinity chromatography. The Coomassie blue staining pattern of the WGA cytoskeletal fraction revealed major protein bands at apparent molecular weights of $>200$ ( 250, 240, 235), 200, 115, 82/78 (a doublet), 56, 43, 36 , and $18 \mathrm{kD}$. Labeling cells with ${ }^{32} \mathrm{PO}_{4}$ before WGA treatment indicated that the cytoskeletal proteins with molecular weights of $115,82 / 78$, and $72 \mathrm{kD}$, and a $40-\mathrm{kD}$ detergent soluble protein, are phosphorylated during activation. The 78 kD cytoskeletal phosphoprotein co-migrates with the lower subunit of erythrocyte (RBC) band 4.1 and shows strong cross-reactivity with RBC anti-band 4.1 antibody. Phosphorylation of cytoskeletal proteins like 4.1 may be involved in the regulation of interactions between GP 140 and the actin-containing cytoskeleton. Unlike the C3bi receptor, GP 140 is a major surface component of unactivated PMNs, has no stoichiometrically related $95-\mathrm{kD}$ subunit, and has two isoforms with pIs in the range of 6.4 to 6.6. Under conditions that result in an increased expression of the $\mathrm{C} 3 \mathrm{bi}$ receptor (such as treatment with the $\mathrm{Ca}^{2+}$ ionophore $\mathrm{A} 23187$ ), the amount of GP 140 on the PMN cell surface appears to be significantly reduced. The interaction of GP 140 with the cytoskeleton during activation suggests that GP 140 may play an important role in neutrophil functional responses.

\section{Introduction}

The association of PMN cell surface membrane proteins with the cytoskeleton is essential for processes such as shape change,

Presented in part at the Annual Meeting of the American Society for Cell Biology, November 1987, St. Louis, MO.

Address reprint requests to Dr. Suchard, Department of Pediatrics, Room 7510, MSRB-1, Box 0684, Ann Arbor, MI 48109.

Received for publication 23 September 1988 and in revised form 13 March 1989.

J. Clin. Invest.

(C) The American Society for Clinical Investigation, Inc. 0021-9738/89/08/0484/09 \$2.00

Volume 84, August 1989, 484-492 chemotaxis, adhesion, cell motility, phagocytosis, and cell-cell recognition. When extracellular ligands (e.g. phagocytic particles, chemotactic peptides, immune complexes, lectins) bind to specific cell surface receptors on PMNs, these cells change shape and reorganize their cytoskeleton (1). During such PMN activation, the resultant ligand-receptor complexes usually aggregate to form small cell surface patches that may redistribute into larger patches and caps (1-3). Extensive immunocytochemical and biochemical studies have led many investigators to suggest that the movement of these ligand-receptor complexes in the plane of the membrane occurs through the direct or indirect interaction of receptors with membrane-associated microfilaments. This hypothesis is further supported by the fact that receptor cap formation is accompanied by a co-recruitment of actin and myosin, and can be inhibited by cytochalasin D or chloropromazine (4-7).

More direct evidence for an interaction between membrane receptors and actin in PMNs is provided by experiments in which the binding of the chemotactic peptide FMLP to FMLP receptors or phagocytic substrate to Fc-receptors leads to the rapid but transient polymerization of actin $(5,8,9)$. Chemotactic peptides appear to promote actin polymerization by increasing the number of available nucleation sites for polymerization (8). Localized induction of actin nucleation sites may in turn determine specific cellular sites for cytoskeletal reorganization, and thus confer directionality to subsequent motility. Concomitant with actin polymerization, the ligandreceptor complex is converted from a fast dissociating (or low affinity) form to a slow dissociating (or high affinity) form (10, 11). Several labs have also demonstrated that following ligand binding, the Con A, Fc, FMLP, CR1, and CR3 (C3bi/MO-1) receptors are recruited to the detergent insoluble actin-containing cytoskeleton of PMNs $(3,4,12-14)$. The specific association of these receptors with actin filaments is further supported by the fact that cytochalasin $D$ blocks the formation of ligand-receptor complexes $(3,12,14)$. Jack et al. (3) have extended these observations by showing that ${ }^{125} \mathrm{I}$-actin binds to Fc and CR3 (C3bi/MO-1) receptors immobilized on Sepharose-Fc/CR3 receptor antibody beads. Whether this binding reflects a direct interaction between the receptor molecules and F-actin or is mediated by membrane and/or cytoskeletalbinding proteins remains to be determined.

In the present study, we have identified a major PMN cell surface glycoprotein (GP 140) that becomes linked to the plasma membrane-associated cytoskeleton after treatment of PMNs with wheat germ agglutinin (WGA), ${ }^{1}$ but not other PMN agonists. An erythrocyte band 4.1 analogue was identified in the WGA-induced cytoskeletal fraction and may participate in linking GP 140 to the actin-based cytoskeleton during activation. GP 140 is distinct from the C3bi (MO-1) receptor

1. Abbreviations used in this paper: ACD, acid citrate dextrose, NGF, nerve growth factor; PM, plasma membrane; TX-100, Triton X-100; WGA, wheat germ agglutinin. 
and its expression on the cell surface is reduced under conditions that increase $\mathrm{C} 3 \mathrm{bi}$ receptor expression. The association of GP 140 with the cytoskeleton during WGA-mediated cell activation suggests its potential importance in PMN functional responses.

\section{Methods}

\section{Cell preparation}

PMNs were isolated from human peripheral blood as previously described (15). Briefly, fresh whole blood was obtained by venipuncture from healthy volunteers and immediately added to acid citrate dextrose (ACD). The PMNs were purified by dextran sedimentation followed by hypotonic lysis to remove the majority of erythrocytes and then centrifuged through Ficoll-Paque (Pharmacia Fine Chemicals, Piscataway, NJ) to remove contaminating mononuclear cells.

\section{$P M N$ cell surface iodination and plasma membrane isolation}

Cells were surface iodinated in PBS for $\mathbf{4 5} \mathrm{min}$ on ice by the lactoperoxidase/glucose oxidase method outlined by Hubbard and Cohn (16). Plasma membranes (PM) were isolated following a modification of Jesaitis et al. (17) by nitrogen cavitation in buffer (8) containing 138 $\mathrm{mM} \mathrm{KCl}, 2 \mathrm{mM} \mathrm{MgCl} 2,10 \mathrm{mM}$ imidazole, $\mathrm{pH} 7.2,1 \mathrm{mM}$ EGTA, 1 $\mathrm{mM}$ DTT, $1 \mathrm{mM}$ PMSF, $1 \mu \mathrm{g} / \mathrm{ml}$ aprotinin, and $1 \mu \mathrm{g} / \mathrm{ml}$ leupeptin. After cavitation, the homogenate was sequentially centrifuged at $350 \mathrm{~g}$ for $6 \mathrm{~min}$ and $1,500 \mathrm{~g}$ for $10 \mathrm{~min}$ to remove unlysed cells, nuclei, cell fragments, and some granules. $10 \mathrm{ml}$ of the $1,500-\mathrm{g}$ supernatant was loaded onto a discontinuous sucrose gradient consisting of $6 \mathrm{ml}$ of $15 \%, 8 \mathrm{ml}$ of $35 \%$, and $6 \mathrm{ml}$ of $50 \%$ sucrose in imidazole buffer plus 200 $\mu \mathrm{g} / \mathrm{ml}$ soybean trypsin inhibitor and centrifuged at $100,000 \mathrm{~g}$ for $2.5 \mathrm{~h}$. An enriched plasma membrane fraction was then recovered by removing material located at the $15 \% / 35 \%$ interface, diluting it with imidazole buffer and centrifuging at $100,000 \mathrm{~g}$ for $45 \mathrm{~min}$. This fractionation scheme was verified by following the differential distribution of specific and azurophilic granules, and the ${ }^{125}$ I-labeling profile on linear sucrose gradients (10). After isolation the PM fraction was analyzed by SDS-PAGE and autoradiography as outlined below. Surface membrane proteins of steady-state (control) or activated PMNs were compared by analyzing PM fractions from cells that were iodinated either before or after activation.

\section{Activation of PMNs with Con A, WGA, FMLP, zymosan-} activated serum, immune complexes, and the calcium ionophore, A23187

Control samples for each of the following activation protocols consisted of the appropriate buffer without added ligand.

Concanavalin A (Con A). PMNs $\left(5 \times 10^{7} / \mathrm{ml}\right)$ were incubated with $20 \mu \mathrm{g} / \mathrm{ml} \mathrm{Con} \mathrm{A}$ in $\mathrm{Ca}^{2+} / \mathrm{Mn}^{2+}$-PBS $(0.1 \mathrm{mM} \mathrm{CaCl}$ and $0.1 \mathrm{mM}$ $\mathrm{MnCl}_{2}$ ) for $5 \mathrm{~min}$ at $37^{\circ} \mathrm{C}$ or $20 \mathrm{~min}$ at $4^{\circ} \mathrm{C}$, washed several times in ice-cold PBS, once in imidazole buffer, and the PM fraction was isolated.

Zymosan-activated serum. Serum diluted to $10 \%$ in PBS, containing $1 \mathrm{mM} \mathrm{MgCl}$ and $0.9 \mathrm{mM} \mathrm{CaCl}$, was activated with $1 \mathrm{mg} / \mathrm{ml}$ zymosan at $37^{\circ} \mathrm{C}$ for $15 \mathrm{~min}$. The zymosan was then removed by centrifugation at $1,000 \mathrm{~g}$ and cells $\left(5 \times 10^{7} / \mathrm{ml}\right)$ were incubated in the activated serum for $10 \mathrm{~min}$ at $37^{\circ} \mathrm{C}$ or $20 \mathrm{~min}$ at $4^{\circ} \mathrm{C}$. The cells were washed several times in PBS before PM isolation.

FMLP. PMNs $\left(5 \times 10^{7} / \mathrm{ml}\right)$ were incubated in $10^{-7} \mathrm{M}$ FMLP for 5 min at $37^{\circ} \mathrm{C}$ or $15 \mathrm{~min}$ at $4^{\circ} \mathrm{C}$ in PBS containing $0.6 \mathrm{mM} \mathrm{CaCl}_{2}$ and 1 $\mathrm{mM} \mathrm{MgCl}_{2}$. The cells were then washed several times in cold PBS and the PM fraction isolated.

Immune complexes. PMNs $\left(10^{7} / \mathrm{ml}\right)$ were incubated with $0.1 \mu \mathrm{g} / \mathrm{ml}$ BSA-anti-BSA immune complex (18) in PBS (containing $0.1 \mathrm{mM}$ $\mathrm{MgCl}_{2}$ and $0.1 \mathrm{mM} \mathrm{CaCl}_{2}$ ) for $15 \mathrm{~min}$ on ice. After incubation, the cells were washed several times in ice-cold PBS before PM isolation.

WGA. PMNs $\left(5 \times 10^{7} / \mathrm{ml}\right)$ were exposed to $10 \mu \mathrm{g} / \mathrm{ml}$ WGA in
$\mathrm{Ca}^{2+} / \mathrm{Mg}^{2+}$-containing PBS ( $0.1 \mathrm{mM}$ of each cation) for $15 \mathrm{~min}$ on ice. The cells were then washed several times in cold PBS and the PM was isolated.

Metabolic labeling of PMNs with ionorganic $\left[{ }^{32} P\right]$ phosphate PMNs $\left(5 \times 10^{7} / \mathrm{ml}\right)$ were labeled in incubation medium $(6 \mathrm{mM}$ Hepes/Tris, pH 7.4, $0.15 \mathrm{M} \mathrm{NaCl}, 10 \mathrm{mM}$ glucose, $5 \mathrm{mM} \mathrm{KCl}, 1 \mathrm{mM}$ $\mathrm{MgCl}_{2}, 0.25 \mathrm{mM} \mathrm{CaCl}_{2}$ ) (19) containing $0.125 \mathrm{mCi} / \mathrm{ml}$ of $\mathrm{H}_{3}{ }^{32} \mathrm{PO}_{4}$ for $2 \mathrm{~h}$ at room temperature. Cells were then incubated in either $\mathrm{Ca}^{2+}$ / $\mathrm{Mg}^{2+}$-PBS $\left(0.1 \mathrm{mM} \mathrm{CaCl} 2\right.$ and $0.1 \mathrm{mM} \mathrm{MgCl}_{2}$ ) alone or in $\mathrm{Ca}^{2+} /$ $\mathrm{Mg}^{2+}$-PBS containing WGA $(10 \mu \mathrm{g} / \mathrm{ml})$ on ice for $15 \mathrm{~min}$. The cells were washed several times with incubation medium minus the glucose before PM isolation. To inhibit phosphatase activity, $10 \mathrm{mM} \mathrm{NaF}$ was included in all solutions used for plasma membrane isolation. In order to identify phosphoproteins associated with the cytoskeleton, PM fractions were extracted in Triton X-100 (TX-100) to separate detergent soluble and insoluble (or cytoskeletal) fractions. Unextracted plasma membrane, cytoskeletal, and soluble fractions were analyzed by SDS-PAGE and autoradiography.

\section{Nonionic detergent extraction}

$T X-100$ extraction. Isolated PM from surface iodinated PMNs was washed in imidazole buffer, $\mathrm{pH} 7.2$, and resuspended in imidazole buffer containing $1 \%$ TX-100 (vol/vol), $1 \mathrm{mM} \mathrm{PMSF,} 1 \mu \mathrm{g} / \mathrm{ml}$ aprotinin, and $1 \mu \mathrm{g} / \mathrm{ml}$ leupeptin. A time course analysis of extraction at $0^{\circ} \mathrm{C}$ indicated that maximal extraction was reached by $10 \mathrm{~min}$. Therefore, all extractions were performed for $10 \mathrm{~min}$. The protein concentration in all samples did not exceed $0.5 \mathrm{mg} / \mathrm{ml}$. The detergent extract was centrifuged at $100,000 \mathrm{~g}$ for $10 \mathrm{~min}$ in an airfuge (Beckman Instruments, Inc., Fullerton, CA). The soluble fraction was removed and the insoluble (cytoskeletal) fraction was resuspended in extraction buffer, transferred to a clean tube, pelleted in the airfuge, and washed at least three times. After centrifugation, either $(a)$ the supernatant (the TX-100-soluble fraction) was fractionated over a WGA-Sepharose column or $(b)$ the supernatant and pellet (the TX-100-insoluble cytoskeletal fraction) were analyzed by SDS-PAGE and autoradiography. The TX-100 insoluble (cytoskeletal) and soluble fractions when combined represented $200 \mu \mathrm{g}$ protein. Obviously, the cytoskeletal fraction from unactivated cells represented far less total protein than that derived from activated cells.

Triton $X-114(T X-114)$ extraction. Isolated PM from untreated (unactivated) surface iodinated PMNs was washed in $10 \mathrm{mM}$ Tris$\mathrm{HCl}, \mathrm{pH} 7.2,150 \mathrm{mM} \mathrm{NaCl}$ and then resuspended in $200 \mu \mathrm{l}$ of the same buffer containing $1 \%(\mathrm{vol} / \mathrm{vol}) \mathrm{TX}-114$. The protein concentration was maintained at $\sim 1 \mathrm{mg} / \mathrm{ml}$. The samples were incubated at $0^{\circ} \mathrm{C}$ for $30 \mathrm{~min}$ with vortexing at 5 -min intervals and then partitioned according to the method of Bordier (20). The resulting lower "detergent" phase and upper "aqueous" phase were then analyzed by SDSPAGE and autoradiography. The lower phase contains both hydrophobic membrane components and any hydrophilic cytoskeletal proteins that are associated with them. In addition, some cytoskeletal proteins will independently cosediment with the detergent micelles.

\section{Western blotting}

$W G A$. Isolated PM was run on SDS-PAGE (6-17\% exponential gradient) as described below followed by transfer to nitrocellulose (21). The nitrocellulose sheet was incubated with $30 \mu \mathrm{g}$ of ${ }^{125}$ I-labeled WGA $(0.3 \mu \mathrm{Ci} / \mu \mathrm{g})$, air dried and analyzed by autoradiography. WGA (E. Y. Labs, San Mateo, CA) was iodinated using the iodogen (Pierce Chemical Co., Rockford, IL) method outlined by Fraker and Speck (22). Parallel blots preincubated with $0.5 \mathrm{M} \mathrm{N}$-acetyl-glucosamine confirmed the specificity of WGA binding.

Immunoblotting. Isolated PM was electrophoresed on a 6-17\% exponential gradient gel and transferred to nitrocellulose (21). The nitrocellulose was subsequently incubated with rabbit polyclonal antibody against the alpha subunit of the C3bi (MO-1) receptor (1:100 dilution) (the generous gift of M. A. Arnaout, Boston Children's Hospital, Boston, MA) followed by incubation with ${ }^{125}$ I-protein A $\left(10^{6}\right.$ 
cpm/ml) (Amersham Corp., Arlington Heights, IL), and analyzed by autoradiography. A parallel lane was incubated with preimmune rabbit serum as a control for nonspecific binding.

The PM TX-100 insoluble PM cytoskeletal fraction was processed by SDS-PAGE followed by transfer to nitrocellulose according to the procedure outlined by Granger and Lazarides (23). Subsequently, the nitrocellulose blot was incubated with rabbit antierythrocyte 4.1 antibody (1:500) (the generous gift of V. Bennett, Duke University, Durham, NC) followed by incubation with ${ }^{125} \mathrm{I}$-protein $\mathrm{A}\left(10^{6} \mathrm{cpm} / \mathrm{ml}\right)$. Preimmune serum replaced anti-4.1 antibody in the negative control samples, and a parallel gel lane of erythrocyte ghosts was run as a positive control.

\section{WGA-Sepharose affinity chromotography}

WGA was conjugated to CNBr-activated Sepharose 4B (Pharmacia Fine Chemicals) at $7 \mathrm{mg} / \mathrm{ml}$ according to the protocol suggested by the manufacturer. PM isolated from ${ }^{125} \mathrm{I}$-labeled cells was extracted with

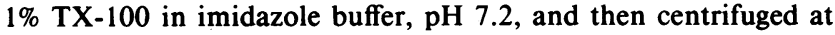
$100,000 \mathrm{~g}$ for $10 \mathrm{~min}$ in a Beckman Airfuge. The resulting supernatant was removed and incubated with $0.5 \mathrm{ml}$ of WGA-Sepharose at $4^{\circ} \mathrm{C}$ overnight with rotation. This material was poured into a $1-\mathrm{ml}$ column and washed with imidazole buffer containing $0.1 \%$ TX-100 until eluate radioactivity reached background levels. Buffer containing 0.5 $\mathrm{M} N$-acetyl-glucosamine was used to elute specific WGA-binding proteins from the column. Specifically eluted fractions were pooled and analyzed by SDS-PAGE and autoradiography.

\section{SDS-polyacrylamide gel electrophoretic and autoradiographic analysis}

Electrophoresis was performed using exponential polyacrylamide gradient $(6.0-17.0 \%)$ gels, 7.5 or $10 \%$ slab gels, and the discontinuous buffer system described by Laemmli (24). All samples were dissolved in sample buffer containing 2.3\% SDS, $0.1 \mathrm{M}$ 2-mercaptoethanol, $0.003 \%$ bromophenol blue, $12.5 \%$ glycerol, $0.063 \mathrm{M}$ Tris- $\mathrm{HCl}, \mathrm{pH} 6.8$, and heated at $100^{\circ} \mathrm{C}$ for $5 \mathrm{~min}$. In general, each gel lane was loaded with $\sim 100 \mu \mathrm{g}$ of protein. In the case of gels showing PM, cytoskeletal, and soluble fractions, the PM lane represented $\sim 100 \mu \mathrm{g}$ protein, whereas the combined cytoskeletal and soluble fractions represented $\sim 200 \mu \mathrm{g}$ protein. Gels were run at a constant current of $15 \mathrm{~mA}$ at room temperature for $4 \mathrm{~h}$ and stained with Coomassie brilliant blue R-250 (Sigma Chemical Co., St. Louis, MO). Gels containing ${ }^{125}$ I-labeled samples were incubated in $\mathrm{En}^{3} \mathrm{Hance}$ (New England Nuclear, Boston, MA), vacuum dried, and exposed to Kodak X-Omat XAR-5 film at $-70^{\circ} \mathrm{C}$.

Two-dimensional gel electrophoresis was performed according to the method of O'Farrell (25) with the following modifications: the first

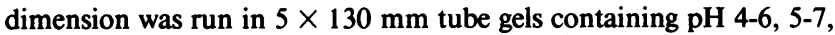
and 3-10 Ampholines (Bio-Rad Laboratories, Richmond, CA) in the ratio of 1:1:2, 9.2 $\mathrm{M}$ urea and $4 \%$ acrylamide. Tube gels were prefocused for $\mathbf{4 5}$ min using progressive 15 -min steps at 300,350 , and 400 V. The PM fractions were solubilized by the method of Wilson et al. (26) by first solubilizing the sample in $1 \%$ SDS, $10 \%$ 2-mercaptoethanol, and $9.0 \mathrm{M}$ urea before adjusting to a final concentration of $9.0 \mathrm{M}$ urea, 2.4\% NP-40, and 2.9\% (wt/vol) Ampholines. Samples were focused for 7,000-7,500 $\mathrm{V}$ hours at room temperature. pH gradients were measured by cutting blank gels run in parallel into $7-\mathrm{mm}$ sections, incubating them in distilled water for $2 \mathrm{~h}$ on a shaker, and then measuring the $\mathrm{pH}$. These $\mathrm{pH}$ gradients were also verified by running parallel gels containing pI standards (Calbiochem-Behring Corp., San Diego, CA). Electrophoresis in the second dimension was performed using $6 \%$ slab gels and the same SDS-PAGE conditions as outlined for one-dimensional gels followed by Coomassie blue staining and autoradiography.

\section{Results}

Recruitment of surface membrane proteins to the cytoskeleton during PMN activation. To assess the recruitment of mem- brane proteins to the cytoskeleton during activation, it is essential to isolate and iodinate PMNs without promoting activation. Additionally, since we are primarily interested in PMassociated cytoskeleton, we conducted all our analyses on PM fractions of PMNs. SDS-PAGE analysis of the PM fraction of PMNs iodinated before activation resolved a number of proteins with apparent molecular weights in the range of 250 to 17 kD (Fig. 1, lane $A$ ). No obvious differences in Coomassie blue staining patterns exist between PM fractions from control (unactivated) and activated cells (compare lanes $A, D$, and $G$ in Fig. 1). The corresponding autoradiograms showed several ${ }^{125}$ I-labeled cell surface proteins with apparent molecular weights ranging from 17 to $200 \mathrm{kD}$, and no apparent differences between control and activated PMNs (Fig. 2, lanes $A, D$, and $G$ ). Treatment of the isolated PM fraction with the nonionic detergent TX-100 solubilized most of the PM proteins (Fig. 1, lanes $C, F$, and $I$ ) leaving an insoluble residue that contained the membrane-associated cytoskeleton (Fig. 1, lanes $B, E$, and $H$ ). When the PM from control cells was extracted with TX-100, few proteins were observed in the cytoskeleton fraction (Fig. 1, lane $B$ ), and no ${ }^{125} \mathrm{I}$-labeled membrane proteins could be detected that were associated with this cytoskeleton (Fig. 2, lane $B$ ).

To determine whether any specific PMN plasma membrane proteins became associated with the cytoskeleton after activation, we isolated PM fractions from activated PMNs ${ }^{125}$ I-surface labeled before activation. These PM fractions were extracted with TX-100 and the soluble and insoluble (cytoskeleton) fractions analyzed by SDS-PAGE and autoradiography.

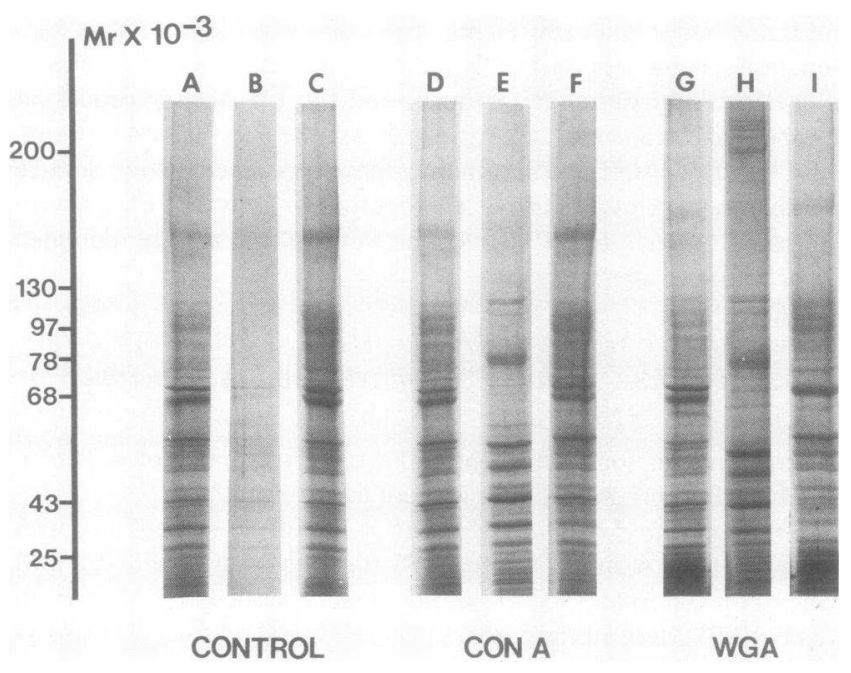

Figure 1. SDS-PAGE analysis of proteins in TX-100 soluble or insoluble fractions of total PM from control (steady-state) and ligandtreated PMNs. Electrophoresis was conducted using an exponential 6-17\% acrylamide gradient. $(A-C)$ PM fraction from control PMNs. The PM fraction represents $\sim 100 \mu \mathrm{g}$ protein whereas the combined TX-100 insoluble and soluble fractions represent $\sim 200 \mu \mathrm{g}$ protein. $(A)$ Total PM fraction. (B) TX-100 insoluble cytoskeletal fraction. (C) TX-100 soluble fraction. (D-F) PM fractions from Con Atreated PMNs. $(D)$ Total PM fraction. (E) TX-100 insoluble cytoskeletal fraction. (F) TX-100 soluble fraction. $(G-I)$ PM fractions from WGA-treated PMNs. $(G)$ Total PM fraction. $(H)$ TX-100 insoluble cytoskeletal fraction. (I) TX-100 soluble fraction. (Molecular weight markers: myosin, $200 \mathrm{kD}$; $\beta$-galactosidase, $130 \mathrm{kD}$; phosphorylase A, $97 \mathrm{kD}$; lactoperoxidase, $78 \mathrm{kD}$; BSA, $68 \mathrm{kD}$; actin, $43 \mathrm{kD}$; Con A, 25 kD.) 
Major surface proteins with apparent molecular weights that ranged from 80 to $13 \mathrm{kD}$ were recruited to the cytoskeleton by Con A, FMLP, zymosan activated serum, and immune complexes (Fig. 2, lane $E$ ). WGA stimulated the recruitment of these proteins, as well as an additional $140-\mathrm{kD}$ protein, to the cytoskeleton (Fig. 2, lane $H$ ).

The Coomassie blue staining pattern of the cytoskeletal fraction from WGA-treated PMNs revealed major protein bands at apparent molecular weights of $>200(\sim 250,240$, 235), 200, 115, 82/78 (a doublet), 56, 43, 36, and $18 \mathrm{kD}$ (Fig. 1 , lane $H$ ). This pattern is qualitatively similar to that observed with other ligands (Fig. 1, lane $E$ ). Cells labeled metabolically with ${ }^{32} \mathrm{PO}_{4}$ before WGA treatment revealed that the 115 , $82 / 78$, and $72 \mathrm{kD}$ cytoskeletal proteins (Fig. 3, lane $E$ ), and a detergent soluble $40-\mathrm{kD}$ protein (Fig. 3 , lane $F$ ), became phosphorylated during WGA-mediated activation.

The 78-kD cytoskeletal phosphoprotein comigrates with the lower subunit of erythrocyte (RBC) band 4.1. Band 4.1 is a cytoskeletal protein that is involved in mediating the interaction between surface membrane proteins and the underlying cytoskeletal network in erythrocytes $(27,28)$. When the cytoskeletal fraction from WGA-treated PMNs was immunoblotted with antibodies against erythrocyte band 4.1 , the band at $78 \mathrm{kD}$, comigrating with the lower subunit of erythrocyte band 4.1 (Fig. 4, lane $A$ ), showed strong cross-reactivity (Fig. 4, lane $B$ ). No staining with preimmune serum was evident (Fig. 4 , lane $C$ ).

To verify that the $140-\mathrm{kD}$ surface iodinated protein recruited to the cytoskeleton with WGA was a WGA-binding protein, and therefore a cell surface glycoprotein (GP 140), we transferred PM from unactivated PMNs and the cytoskeletal

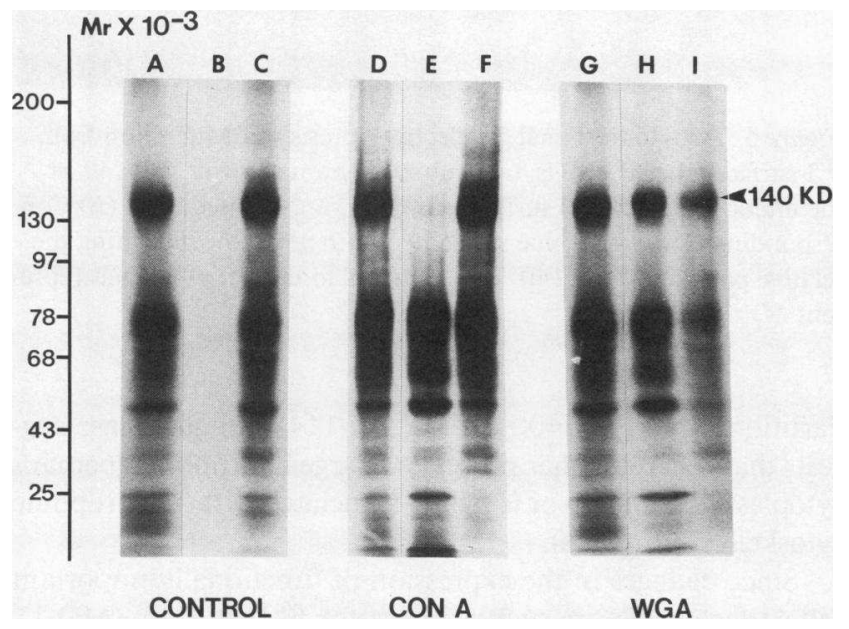

Figure 2. SDS-PAGE analysis and autoradiography of ${ }^{125} \mathrm{I}$-surface labeled proteins in TX-100 soluble or insoluble fractions of total plasma membrane from control and ligand-treated PMNs. These autoradiograms correspond to the Coomassie blue stained gel lanes in Fig. 1. $(A-C)$ PM fractions from control PMNs. $(A)$ Total PM fraction. (B) TX-100 insoluble cytoskeletal fraction. $(C)$ TX-100 soluble fraction. $(D-F)$ PM fractions from Con A-treated PMNs. [Similar results were obtained with FMLP, zymosan-activated serum, and immune complexes.] (D) Total PM fraction. $(E)$ TX-100 insoluble cytoskeletal fraction. (F) TX-100 soluble fraction. $(G-I)$ PM fractions from WGA-treated PMNs. $(G)$ Total PM fraction. $(H)$ TX-100 insoluble cytoskeletal fraction. Note the recruitment of a ${ }^{125}$ I-labeled $140 \mathrm{kD}$ protein to this fraction. (I) TX-100 soluble fraction.

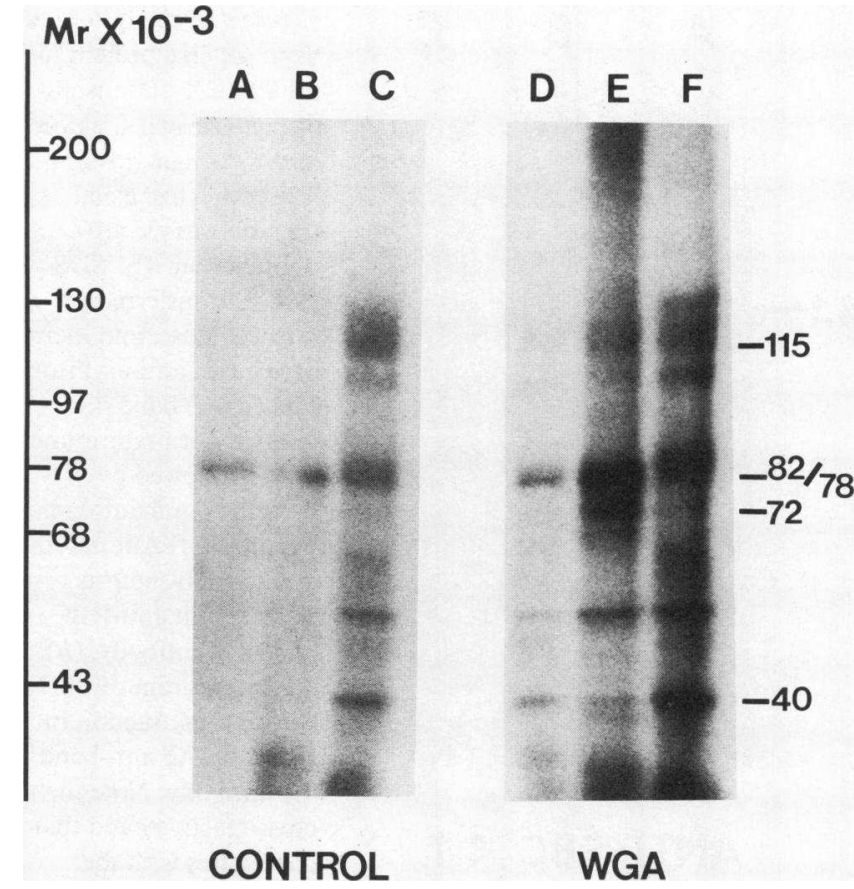

Figure 3. Autoradiograms of ${ }^{32} \mathrm{P}$-labeled proteins from control and WGA-treated PMNs. SDS-PAGE was performed using an exponential gradient of 6-17\% acrylamide. $(A-C)$ PM fractions from control PMNs. (A) Total PM fraction. (B) TX-100 insoluble cytoskeletal fraction. (C) TX-100 soluble fraction. (D-F) PM fractions from WGA-treated PMNs. (D) Total PM fraction. (E) TX-100 insoluble cytoskeletal fraction. $(F)$ TX-100 soluble fraction. Note that the 115 , $82 / 78$, and $72 \mathrm{kD}$ cytoskeletal proteins (lane $E$ ) and a soluble $40 \mathrm{kD}$ protein (lane $F$ ) are phosphorylated after exposure of PMNs to WGA.

fraction from WGA-activated PMNs to nitrocellulose and probed the blot with ${ }^{125}$ I-WGA. GP 140 and a glycoprotein at $\sim 85-90 \mathrm{kD}$ were the major WGA-binding proteins in both the PM and cytoskeletal fractions identified by this assay (Fig. 5, lanes $A$ and $B$ ). WGA-Sepharose chromotography was performed to support the blotting results and more clearly identify cell surface WGA-binding proteins. Using this technique we identified GP 140 as a major PM-associated WGA-binding protein along with another ${ }^{125}$ I-labeled glycoprotein at about $80 \mathrm{kD}$ (Fig. 5, lane $E$ ). The labeling of GP 140 in the cytoskeletal fraction is not as intense as one might expect, probably the result of adding unlabeled WGA to cells in order to activate them. The binding of GP 140 by WGA was specific since $(a)$ $N$-acetyl-glucosamine (GlcNac) specifically eluted GP 140 from the WGA-Sepharose column (Fig. 5, lane $E$ ), and (b) GlcNac blocked the binding of ${ }^{125}$ I-WGA to GP 140 on Western blots (Fig. 5, lanes $C$ and $D$ ).

Characterization of PMN GP 140. Two-dimensional (2-D) gel electrophoresis of PM fractions isolated from ${ }^{125}$ I-labeled PMNs revealed that GP 140 was the major iodinated cell surface protein in unactivated cells, and had two predominant isoforms with pIs of 6.4 and 6.6 (Fig. $6 \mathrm{~A}$ ). Like many other glycoproteins, GP 140 stains poorly with Coomassie blue and is not apparent on the corresponding Coomassie blue-stained 2-D gel (Fig. 6 B).

When the PM from surface iodinated control (unactivated) PMNs was extracted and partitioned using TX-114, most of the ${ }^{125}$ I-labeled membrane proteins readily partitioned into the 


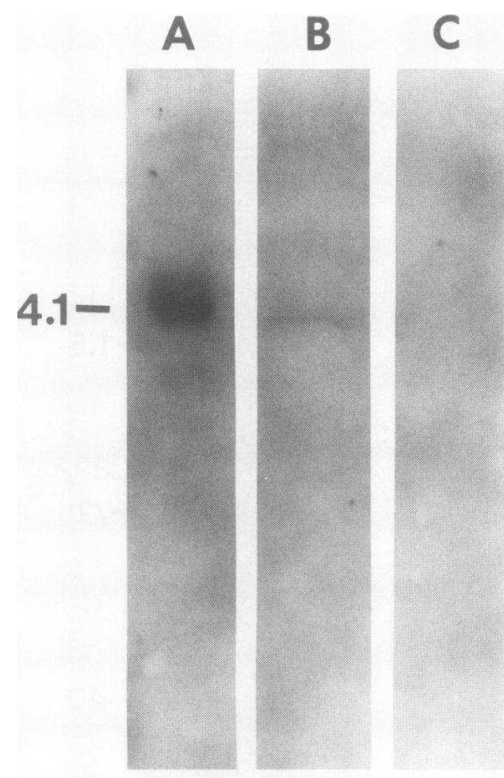

ANTI-RBC 4.1
Figure 4. Detection of a band 4.1-like protein in the PM TX-100 insoluble cytoskeletal fraction of WGA-treated PMNs. The PM cytoskeletal fraction was electrophoresed on $10 \%$ SDSPAGE, transferred to nitrocellulose, and incubated with anti-erythrocyte (RBC) band 4.1 antibody or preimmune serum followed by ${ }^{125} \mathrm{I}-$ protein $\mathrm{A}$ and autoradiography. (A) Autoradiogram of RBC ghosts treated with anti-RBC band 4.1 antibody. (B) Autoradiogram of PMN cytoskeletal fraction incubated with anti-band 4.1 antibody. Note the cross-reactive band that comigrates with the 78-kD polypeptide of erythrocyte band 4.1. (C) Autoradiogram of PMN cytoskeletal fraction incubated with preimmune serum.

"detergent" phase (Fig. 7, lane $C$ ) as might be predicted for integral membrane proteins. In contrast, GP 140 selectively partitioned into the "aqueous" phase along with the majority of hydrophilic cytoskeletal proteins (Fig. 7, lanes $D$ and $B$ ).

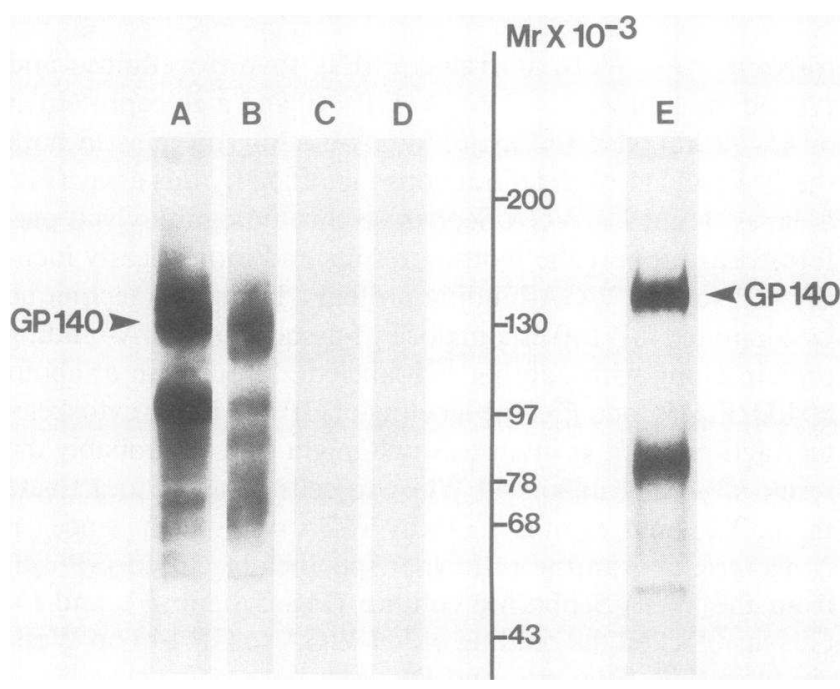

Figure 5. Identification of WGA-binding proteins in the PMN plasma membrane and cytoskeletal fractions. $(A)$ Autoradiogram of total PM processed by SDS-PAGE, transferred to nitrocellulose, and then incubated with ${ }^{125} \mathrm{I}$-labeled WGA. (B) Autoradiogram of TX-100 insoluble cytoskeletal fraction treated identically to lane $A$. $(C$ and $D$ ) Autoradiogram of PM and cytoskeletal fractions treated identically as in lanes $A$ and $B$ but incubated with $0.5 \mathrm{M} N$-acetylglucosamine (GlcNac) before the addition of ${ }^{125}$ I-WGA; $C=$ PM, $D$ $=$ cytoskeleton. $(E)$ Autoradiogram of ${ }^{125}$ I-surface labeled detergent solubilized PM proteins that bound to a WGA-Sepharose column and were specifically eluted with GlcNac. The molecular weight markers refer to lane $E$ only.

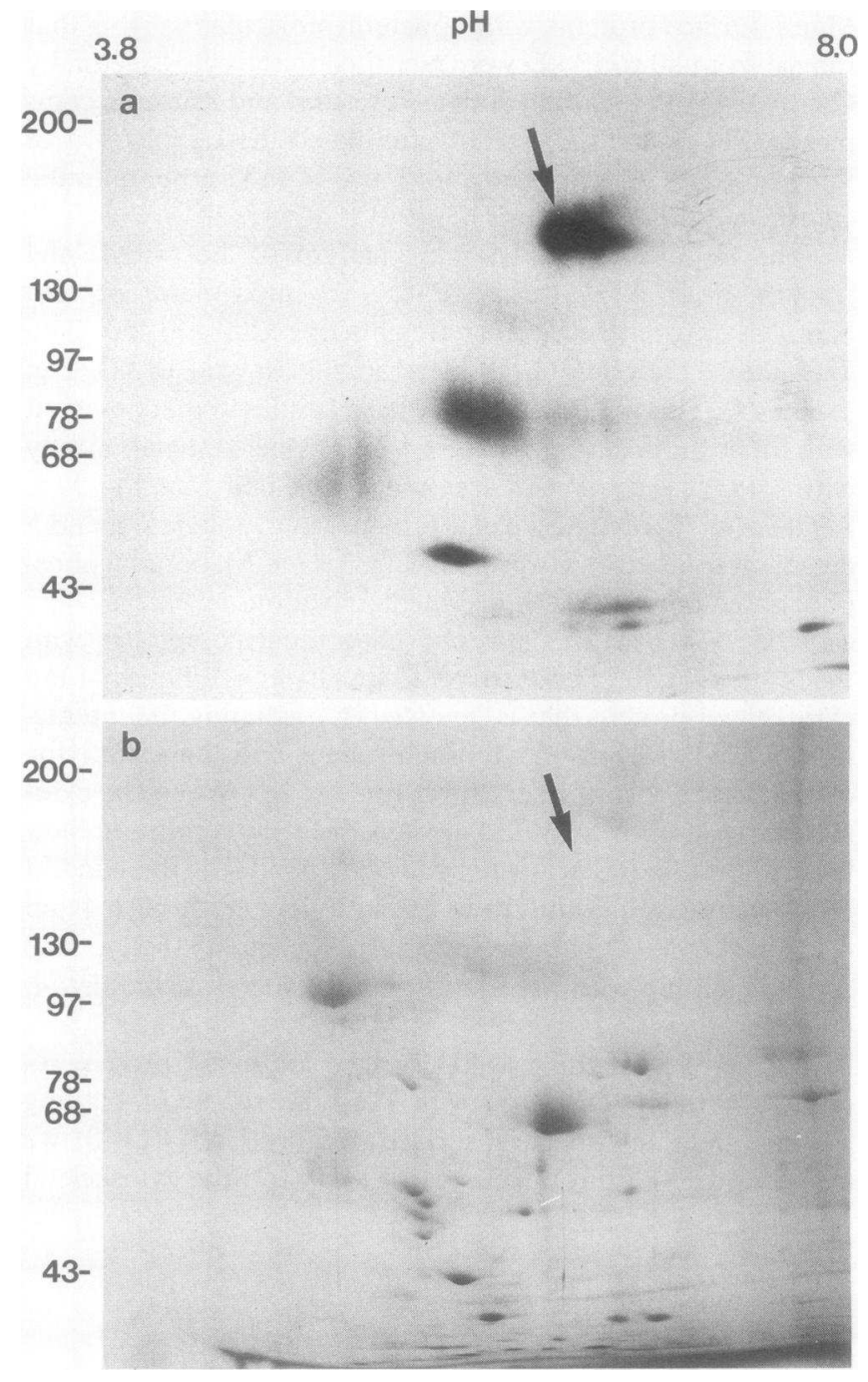

Figure 6. Two-dimensional gel electrophoresis of PM fraction from ${ }^{125}$ I-surface labeled PMNs. $(A)$ Autoradiogram showing GP 140 as the major iodinated cell surface protein in unactivated cells. $(B)$ Corresponding Coomassie blue stained gel with an arrow indicating the relative position of GP 140 . The numbers to the left of the gels represent $M_{\mathrm{r}} \times 10^{-3}$.

Partitioning of GP 140 into the TX-114 aqueous phase suggests that GP 140 either possesses a large hydrophilic (perhaps cytoplasmic) domain or is tightly associated with a hydrophilic cytoskeletal protein(s).

Since changes in the expression of functionally important cell surface receptors such as those for FMLP, C3bi (MO-1), and laminin have been linked to PMN activation (29-33), we examined the pattern of iodinated cell surface proteins following activation with the calcium ionophore, A23187. We exposed PMNs to $10^{-7} \mathrm{M} A 23187$ for $15 \mathrm{~min}$ at $37^{\circ} \mathrm{C}$, surface iodinated the cells, and then isolated the PM fraction. Under these conditions, as compared to control PM (Fig. 8, lane $C$ ), the amount of GP 140 was reduced and there was a concomitant increase in both a 155 - and $95-\mathrm{kD}$ protein (Fig. 8, lane $D$ ). It is likely that the 155 - and $95-\mathrm{kD}$ polypeptides represent the alpha and beta subunits, respectively, of the C3bi (MO-1) receptor since MO-1 surface antigen expression has been shown to increase after treatment of PMNs with A23187 (31). The 


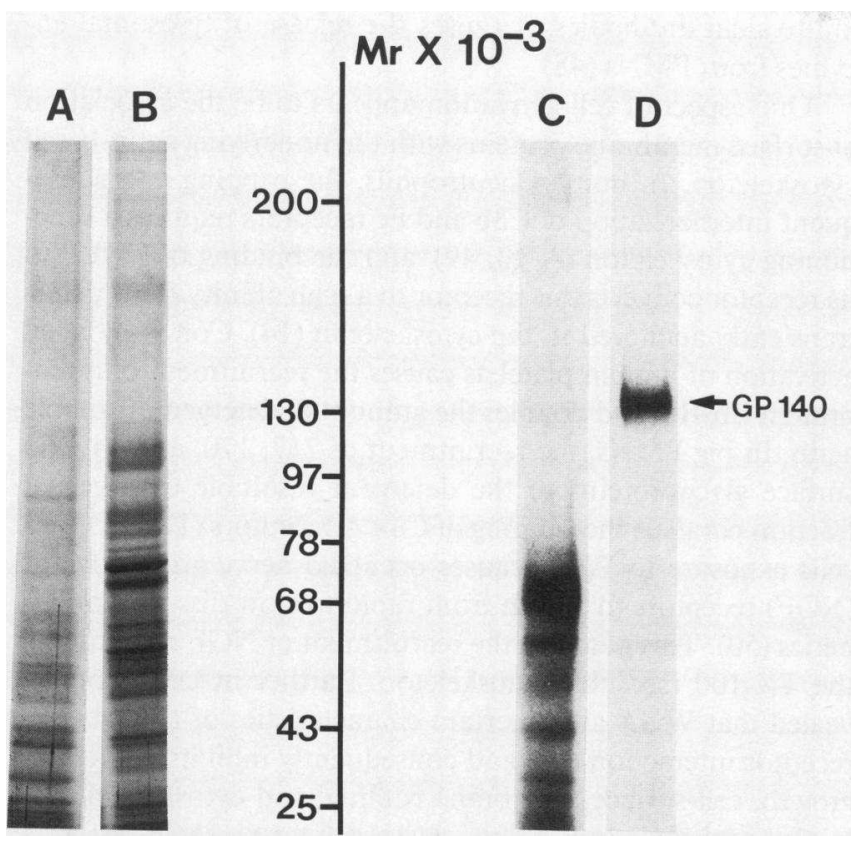

Figure 7. SDS-PAGE analysis of Triton X-114 extracted and partitioned PM fraction from ${ }^{125}$ I-labeled PMNs. $(A)$ Coomassie Blue staining pattern of the TX-114 detergent phase. $(B)$ Coomassie blue staining pattern of the TX-114 aqueous phase. $(C)$ Autoradiogram of the TX-114 detergent phase shown in lane $A$. (D) Autoradiogram of the TX-114 aqueous phase shown in lane $B$. Note the presence of GP 140 in the TX-114 aqueous phase.

155-kD polypeptide band was confirmed as the MO-1 alpha subunit by immunoblotting with an anti-MO-1 alpha subunit antibody (Fig. 8, lanes $E$ and $F$ ). The reduction of GP 140 on the cell surface following activation is also suggested by the reduced amount of GP 140 available for surface labeling on neutrophil cytoplasts (data not shown). No differences in SDS-PAGE Coomassie blue staining patterns between PM fractions isolated from control and A23187-treated PMNs were observed in the high molecular weight range. There was, however, the apparent loss of a doublet at $\sim 68 \mathrm{kD}$ (Fig. 8, compare lanes $A$ and $B$ ). The disappearance of this band could be related to the reduction of GP 140 in A23187-treated PMNs and requires further investigation.

\section{Discussion}

PMN plasma membrane-associated cytoskeleton. In the present study, we have identified a WGA-binding protein (GP 140) that is recruited to the detergent-insoluble cytoskeleton following exposure of the PMNs to subagglutinating concentrations of WGA. When other soluble stimuli such as Con A, FMLP, immune complexes, or zymosan-activated serum are used to activate PMNs, GP 140 is not associated with the cytoskeleton and remains in the detergent soluble fraction. In order to assess recruitment of membrane proteins to the cytoskeleton during activation, it is crucial to be able to prepare PMNs and iodinate surface membrane proteins without causing activation since activation has been shown to alter the state of actin polymerization and membrane-cytoskeleton interactions. We accomplished this and demonstrated that the detergent-insoluble cytoskeleton was a minor component of unactivated cells. Since we are primarily interested in the membrane-associated cytoskeleton, we have conducted all our analyses on the PM

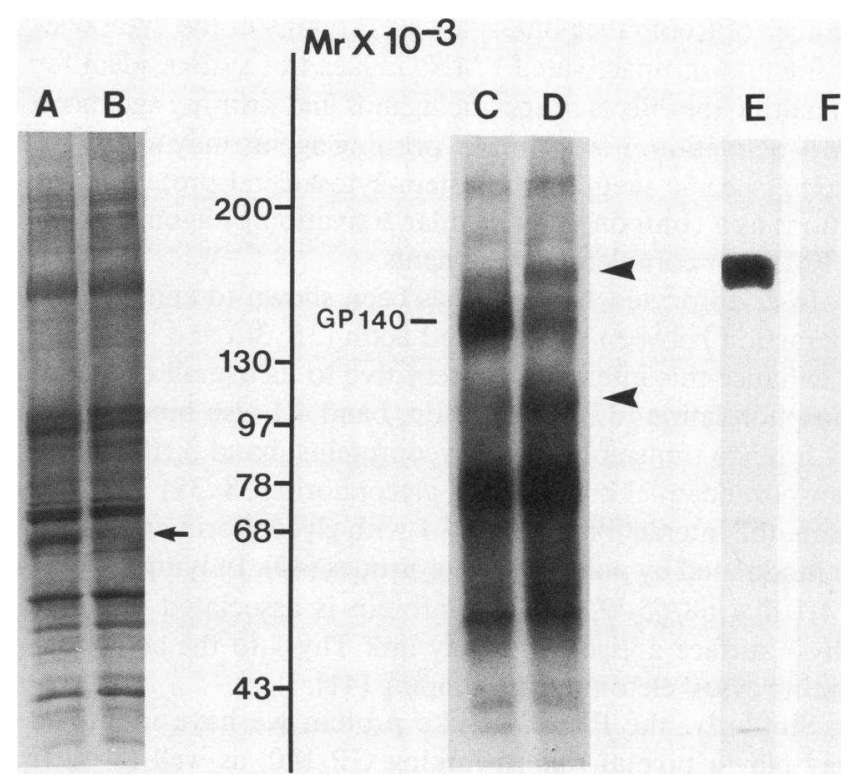

Figure 8. Effect of A23187 on the expression of PMN ${ }^{125}$ I-surface labeled membrane proteins. SDS-PAGE analysis (7.5\% acrylamide) of PM fraction isolated from PMNs iodinated before (control) or after exposure to $10^{-7} \mathrm{M} \mathrm{A23187}$. (A) Coomassie blue staining pattern of PM from control PMNs. (B) Coomassie blue staining pattern of PM from A23187-treated PMNs. Note the reduced amount of the 68-kD doublet (arrow). (C) Autoradiogram of PM from control PMNs. (D) Autoradiogram of PM from A23187-treated PMNs. Note the reduction in intensity of GP 140, and a corresponding increase in ${ }^{125} \mathrm{I}$-labeled polypeptide bands at 155 and $95 \mathrm{kD}$ (arrowheads). (E-F) PMN cell lysates were electrophoresed on 7.5\% SDS-PAGE, transferred to nitrocellulose, and incubated with anti-MO-1 alpha subunit antibody, or preimmune serum followed by ${ }^{125} \mathrm{I}$-protein $\mathrm{A}$ and autoradiography. $(E)$ Autoradiogram of cell lysate treated with anti-MO1 antibody. Note the cross-reactive band that comigrates with the 155-kD polypeptide (lane $D$ ) expressed after A23187 treatment. $(F)$ Autoradiogram of cell lysate incubated with preimmune serum.

fraction of PMNs. This is in contrast to other studies where cytoskeletal fractions are obtained by detergent extraction of whole cells and the authors are unable to distinguish which cytoskeletal proteins are directly associated with the PM. Nevertheless, we have confirmed that the recruitment pattern of surface proteins to the cytoskeleton that we observed in our PM fractions was the same as that observed when whole cells were detergent extracted to obtain cytoskeletal fractions (data not shown).

Fox et al. (34) have demonstrated that platelets isolated at $37^{\circ} \mathrm{C}$ contain $\sim 40 \%$ polymerized actin, whereas platelets isolated at $4^{\circ} \mathrm{C}$ contain $\sim 90 \%$ polymerized actin. The difference in $\mathrm{F}$-actin content was attributed to actin polymerization during cell activation at $4^{\circ} \mathrm{C}$. Unactivated PMNs have only a small amount of actin and other proteins associated with the PM-derived detergent insoluble cytoskeleton (Fig. 1, lane $B$ ). This parallels observations in whole platelet extracts where the major detergent insoluble protein is actin (34). Upon PMN activation, the amount of cytoskeleton-associated proteins, especially proteins with molecular weights consistent with those of actin and myosin, and a band 4.1-like protein increase significantly in the plasma membrane-associated cytoskeleton (Fig. 1, lanes $E$ and $H$ ). An analogous recruitment of actin, myosin, actin-binding protein, and $\alpha$-actinin to the detergent insoluble cytoskeleton occurs during platelet activation (34). 
The absence of ${ }^{125} \mathrm{I}$-labeled membrane proteins and small number of Coomassie blue-staining proteins in the cytoskeletal fraction of unactivated PMNs makes this system ideal for evaluating the effects of specific ligands and priming agents on PMN activation. For example, priming agents may act by inducing specific membrane protein-cytoskeletal protein interactions as a component of cellular activation by agonists such as FMLP or complement fragments.

In erythrocytes, band 4.1 has been shown to enhance the interaction between spectrin and actin $(35,36)$ and its ability to enhance this interaction is sensitive to its overall degree of phosphorylation (37). In addition, band 4.1 also binds to the erythrocyte transmembrane glycoproteins, band 3 (the anion transport channel protein) and glycophorin $(38,39)$. Furthermore, the interaction of band 4.1 with glycophorin appears to be modulated by polyphosphoinositides (40). In lymphocytes, a 4.1-like $68 / 65-\mathrm{kD}$ phosphoprotein is associated with the Thy-1 surface antigen and may link Thy-1 to the actin-containing cytoskeleton during capping (41).

Similarly, the PMN 4.1-like protein we have identified may play a pivotal role in linking GP 140, as well as other surface receptors, to the cytoskeleton during activation in PMNs. The WGA-induced cytoskeletal fraction contains a 82/78-kD phosphoprotein doublet that cross-reacts with anti-4.1 antibody. However, only the $78-\mathrm{kD}$ polypeptide band appears to share antigenic properties with erythrocyte band 4.1. It may be that the $78-\mathrm{kD}$ subunit is the more highly conserved of the two polypeptides that comprise the band 4.1-like protein. This is true of nonerythroid spectrins where the $240,000-\mathrm{kD}$ alpha subunit is highly conserved and the beta subunit is variable $(42,43)$.

Our observation of a 78-kD 4.1-like protein in PMNs is different from that of Spiegel et al. (44) who report a $68-\mathrm{kD}$ immunoreactive form of band 4.1 in PMNs. Since their experiments were performed on whole cell extracts, it is possible that these authors detected a proteolytic fragment of the 78-kD protein. In contrast to the DFP pretreatment used by Spiegel et al. (44), we used a cocktail of protease inhibitors (aprotinin, leupeptin, PMSF, soybean trypsin inhibitor) throughout the PM isolation procedure and did not detect proteolysis of membrane proteins.

PMN WGA-binding proteins. Unlike Perez et al. (45) who saw a single polypeptide band at $62 \mathrm{kD}$ on blots of PM fractions treated with WGA followed by anti-WGA antibody, we did not find a singular WGA-binding protein of $62 \mathrm{kD}$ in our PM fraction of PMNs. After WGA-Sepharose affinity chromatography we observed major ${ }^{125} \mathrm{I}$-labeled proteins at 140 and 80 $\mathrm{kD}$. We did, however, detect a minor WGA-binding protein at $66 \mathrm{kD}$ on Western blots and a poorly resolved cluster of proteins in the $60-68-\mathrm{kD}$ range by WGA-Sepharose chromatography (Fig. 5). Other possible targets of WGA binding are the LFA-1/Mac-1/gp 150,95 family of glycoproteins that have been reported to bind to and specifically elute from Con A, WGA, and Ricinus communis affinity columns (46). Since these receptors are not abundant on unactivated PMNs, it is not surprising that these proteins were not identified in our preparations.

In addition to being used to identify cell surface glycoproteins, WGA has been used as a cell surface stimulus to study PMN functional responses. A subagglutinating concentration of WGA completely inhibits FMLP-mediated chemotaxis of human PMN, but has no effect on $\left[{ }^{3} \mathrm{H}\right] \mathrm{FMLP}$ binding, FMLP-induced degranulation, or FMLP-mediated superoxide generation (47). However, if the WGA is cross-linked with multivalent antibodies, it causes the release of lysosomal enzymes from PMNs (48).

One aspect of cell activation appears to be the association of surface membrane proteins with the underlying actin-based cytoskeleton. In human neutrophils, the capping and subsequent internalization of $\mathrm{C} 3 \mathrm{~b}$ and $\mathrm{Fc}$ receptors requires a functioning cytoskeleton $(4,13,49)$, and the binding of FMLP to its receptor converts this receptor to a high affinity form that is transiently anchored to the cytoskeleton (14). Con A-induced activation of human platelets causes the recruitment of glycoprotein IIb/IIIa and doubles the amount of detergent insoluble actin. In pig PMNs, the recruitment of 217,170 , and $147 \mathrm{kD}$ surface glycoproteins to the detergent insoluble cytoskeletal fraction parallels the capping of Con A receptors (12). In PC12 cells exposure to WGA causes occupied nerve growth factor (NGF) receptors to switch from rapid to slow dissociation kinetics (50). This parallels the recruitment of NGF receptors to the TX-100 insoluble cytoskeleton. Further investigation revealed that WGA alters certain characteristics of NGF/NGFreceptor interaction (51) and consequently inhibits nerve outgrowth, cell-surface membrane ruffling, and cytoskeletal protein phosphorylation. Although we cannot presently assign a function to GP 140, it is likely that its specific association with the cytoskeleton is functionally significant.

GP 140 is distinct from the C3bi (MO-1) receptor. The abundance of GP 140 on the surface of unactivated PMNs and the reduction of this glycoprotein on the cell surface after activation with the calcium ionophore, A23187, suggests that GP 140 differs from MO-1. That GP 140 and the MO- 1 alpha subunit are distinct entities was demonstrated on Western blots using anti-MO-1 alpha subunit antibody. Analysis by 2-D gel electrophoresis resolves two isoforms of GP 140 with pIs ranging from 6.4 to 6.6. The GP 140 isoforms are more basic than the MO-1 alpha subunit from monocytes which has a pI between 5.9 to 6.1 (52). These glycoproteins are also distinct from the AHN-1 antigen of Skubitz et al. (53) that has an acidic pI of 4.5. In contrast to MO-1 which partitions into the hydrophobic detergent phase following TX-114 extraction and purification (54), GP 140 partitions into the TX-114 aqueous phase. This partitioning behavior is not unique to GP 140 since lymphocyte and platelet integral membrane glycoproteins have also been shown to partition into the TX-114 aqueous phase away from the majority of other membrane proteins $(42,55)$. Additionally, when GP 140 was isolated by either TX-114 partitioning or WGA-Sepharose chromotography (Fig. 7, lane $D$ and Fig. 3, lane $C$ ), no stoichiometrically related $95-\mathrm{kD}$ polypeptide was observed. It appears that GP 140 is distinct from MO-1, LFA, and p150,95, all PMN adhesion glycoproteins that share a common $95-\mathrm{kD}$ subunit.

A major WGA-binding protein on the surface of fibroblasts is the $140-\mathrm{kD}$ fibronectin (Fn) receptor $(56,57)$. In PMNs, preliminary studies indicate that the Fn receptor is a 150-170$\mathrm{kD}, 95-110-\mathrm{kD}$ dimer similar to the platelet $\mathrm{RGD}$ receptor (58). SDS-PAGE analysis of both total PM and TX-114 aqueous fractions under nonreducing and reducing conditions had no appreciable affect on the mobility of GP 140 and failed to reveal a dimeric composition (data not shown). Since the fibronectin receptor identified by Brown and Goodwin (58) is not a major PM component of unactivated PMNs and is dimeric in nature, it is unlikely that GP 140 corresponds to the Fn receptor of PMNs.

Unlike MO-1, GP 140 surface expression does not increase 
following treatment of PMNs with the calcium ionophore, A23187. In fact, the amount of GP 140 on the surface of PMNs, as detected by glucose oxidase/lactoperoxidase iodination, is greatly reduced following A23187 activation. This result agrees with Mollinedo (59) who observed a reduction in iodinated GP 140 on activated PMNs and on the surface of cytoplasts. The observed loss of a surface receptor is not novel for PMNs. Bender et al. (60) noted that C5a receptors were greatly reduced on the surface of PMNs following activation while FMLP and casein receptor expression increased significantly.

The concomitant loss of a $68-\mathrm{kD}$ Coomassie blue staining doublet from the PM fraction of A23187-activated PMNs (Fig. 8 , lane $B$ ) suggests that there may be some interaction between this $68-\mathrm{kD}$ doublet polypeptide and GP 140 . In contrast to published reports (61-63), no differences between Coomassie blue staining patterns of control and A23187-treated PMNs were observed in the high molecular weight range. This is interesting since there has often been a correlation between the appearance (or disappearance) of a high molecular weight Coomassie blue-staining polypeptide band and the presence (or loss) of the 155-kD alpha subunit of MO-1 (61-63).

Alterations in the function and amount of various cytoskeletal proteins have been implicated in several inherited and acquired defects of leukocyte function (64). Since the majority of functional abnormalities in glycoprotein-deficient PMNs involve motility-related events such as adhesion, spreading on a substrate, migration or phagocytosis, impairment of the cytoskeleton and/or membrane-cytoskeleton interactions in these cells is indicated. Since tight adherence to and spreading of cells on various substrates appears to require the specific interation of F-actin filaments with the membrane $(65,66)$, the failure of cells to spread may reflect an absence of cell surface adhesive glycoproteins and/or a failure in transmembrane signaling mechanisms necessary for actin polymerization or cytoskeletal reorganization. Characterization of cell surface receptors, such as GP 140, and their relationship to the underlying cytoskeleton can provide unique insights into the mechanisms that regulate cell surface receptors during PMN activation.

\section{Acknowledgments}

This work was supported by National Institutes of Health grants AI-26863, AI-20065, and HL-31963.

\section{References}

1. Oliver, J. M., and R. D. Berlin. 1983. Surface and cytoskeletal events regulating leukocyte membrane topography. Semin. Hematol. 20:282-304.

2. Dykman, T. R., J. A. Hatch, and J. P. Atkinson. 1984. Polymorphism of the human C3b/C4b receptor. J. Exp. Med. 159:691703.

3. Jack, R. M., R. M. Ezzell, J. Hartwig, and D. T. Fearon. 1986. Differential interaction of the $\mathrm{C} 3 \mathrm{~b} / \mathrm{C} 4 \mathrm{~b}$ receptor and MHC class I with the cytoskeleton of human neutrophils. J. Immunol. 137:3996-4003.

4. Jack, R. M., and D. T. Fearon. 1984. Altered surface distribution of both $\mathrm{C} 3 \mathrm{~b}$ receptors and $\mathrm{Fc}$ receptors on neutrophils induced by anti-C3b receptor or aggregated IgG. J. Immunol. 132:3028-3033.

5. Fechheimer, M., and S. H. Zigmond. 1983. Changes in cytoskeletal proteins of polymorphonuclear leukocytes induced by chemotactic peptides. Cell. Motil. 3:349-361.

6. Oliver, J. M., R. Lalchandani, and E. L. Becker. 1977. Actin redistribution during Concanavalin A cap formation in rabbit neutrophils. J. Reticuloendothel. Soc. 21:357-364.
7. Bourguignon, L. Y. W., and S. J. Singer. 1977. Transmembrane interactions and the mechanism of capping of surface receptors by their specific ligands. Proc. Natl. Acad. Sci. USA. 74:5031-5035.

8. Carson, M., A. Weber, and S. H. Zigmond. 1986. An actin-nucleating activity in polymorphonuclear leukocytes is modulated by chemotactic peptides. J. Cell. Biol. 103:2707-2714.

9. Howard, T. H., and C. O. Oresajo. 1985. The kinetics of chemotactic peptide-induced change in F-actin content, F-actin distribution, and the shape of neutrophils. J. Cell Biol. 101:1078-1085.

10. Jesaitis, A. J., J. R. Naemura, R. G. Painter, L. A. Sklar, and C. G. Cochrane. 1983. The fate of an $\mathrm{N}$-formylated chemotactic peptide in stimulated human granulocytes. J. Biol. Chem. 258:1968-1977.

11. Zigmond, S. H., and A. W. Tranquillo. 1986. Chemotactic peptide binding by rabbit polymorphonuclear leukocytes. J. Biol. Chem. 261:5283-5288.

12. Sheterline, P., and C. R. Hopkins. 1981. Transmembrane linkage between surface glycoproteins and components of the cytoplasm in neutrophil leukocytes. J. Cell Biol. 90:743-754.

13. Sheterline, P., J. E. Rickard, and R. C. Richards. 1984. Fc receptor-directed phagocytic stimuli induce transient actin assembly at an early stage of phagocytosis in neutrophil leukocytes. Eur. J. Cell Biol. 34:80-87.

14. Jesaitis, A. J., J. R. Naemura, L. A. Sklar, C. G. Cochrane, and R. G. Painter. 1984. Rapid modulation of N-formyl chemotactic peptide receptors on the surface of human granulocytes: formation of high-affinity ligand-receptor complexes in transient association with cytoskeleton. J. Cell Biol. 98:1378-1387.

15. Curnutte, J. T., B. M. Babior, and M. L. Karnovsky. 1979. Fluoride-mediated activation of the respiratory burst in human neutrophils. J. Clin. Invest. 63:637-647.

16. Hubbard, A. L., and Z. A. Cohn. 1972. The enzymatic iodination of the red cell membrane. J. Cell Biol. 55:390-405.

17. Jesaitis, A. J., J. R. Naemura, R. G. Painter, L. A. Sklar, and C. G. Cochrane. 1982. Intracellular localization of N-formyl chemotactic receptor and $\mathrm{Mg}^{2+}$ dependent ATPase in human granulocytes. Biochim. Biophys. Acta. 719:556-568.

18. Scherzer, H., and P. A. Ward. 1978. Lung injury produced by immune complexes of varying composition. J. Immunol. 121:947952.

19. Cockcroft, S. 1986. The dependence on $\mathrm{Ca}^{2+}$ of the guaninenucleotide-activated polyphosphoinositide phosphodiesterase in neutrophil plasma membranes. Biochem. J. 240:503-507.

20. Bordier, C. 1981. Phase separation of integral membrane proteins in Triton X-114 solution. J. Biol. Chem. 256:1604-1607.

21. Towbin, H., T. Staehlin, and J. Gordon. 1979. Electrophoretic transfer of proteins from polyacrylamide gels to nitrocellulose sheets: procedure and some applications. Proc. Natl. Acad. Sci. USA. 76:4350-4355.

22. Fraker, P. J., and J. C. Speck. 1978. Protein and cell membrane iodinations with a sparingly soluble chloramide, 1,3,4,6-tetrachloro3a,6a-diphenyl-glycoluril. Biochem. Biophys. Res. Commun. 80:849857.

23. Granger, B. L., and E. Lazarides. 1984. Membrane skeletal protein 4.1 of avian erythrocytes is composed of multiple variants that exhibit tissue-specific expression. Cell. 37:595-607.

24. Laemmli, U. K. 1970. Cleavage of structural proteins during the assembly of the head of bateriophage T-4. Nature (Lond.). 227:680-685.

25. O'Farrell, P. H. 1975. High resolution two-dimensional electrophoresis of proteins. J. Biol. Chem. 250:4007-4021.

26. Wilson, D. L., G. E. Hall, G. C. Stone, and R. W. Rubin. 1977. Some improvements in two-dimensional gel electrophoresis of proteins. Anal. Biochem. 83:33-44.

27. Schiffer, K. A., and S. R. Goodman. 1984. Protein 4.1: its association with the human erythrocyte membrane. Proc. Natl. Acad. Sci. USA. 81:4404-4408.

28. Pasternack, G. R., R. A. Anderson, T. L. Leto, and V. T. Marchesi. 1985. Interactions between protein 4.1 and band 3. J. Biol. Chem. 260:3676-3683. 
29. Gardner, J. P., D. A. Melnick, and H. L. Malech. 1986. Characterization of the formyl peptide chemotactic receptor appearing at the phagocytic cell surface after exposure to phorbol myristate acetate. $J$. Immunol. 136:1400-1405.

30. Berger, M., J. O'Shea, A. S. Cross, T. M. Folks, T. M. Chused, E. J. Brown, and M. M. Frank. 1984. Human neutrophils increase expression of $\mathrm{C} 3 \mathrm{bi}$ as well as $\mathrm{C} 3 \mathrm{~b}$ receptors upon activation. J. Clin. Invest. 74:1566-1571.

31. Todd, R. F., III, M. A. Amaout, R. E. Rosin, C. A. Crowley, W. A. Peters, and B. M. Babior. 1984. Subcellular localization of the large subunit of $\mathrm{Mol}\left(\mathrm{Mol}_{\alpha}\right.$; formerly gp 110), a surface glycoprotein associated with neutrophil adhesion. J. Clin. Invest. 74:1280-1290.

32. Yoon, P. S., L. A. Boxer, L. A. Mayo, A. Y. Yang, and M. S. Wicha. 1987. Human neutrophil laminin receptors: activation-dependent receptor expression. J. Immunol. 138:259-265.

33. Anderson, T. C., C. Dahlgren, P. O. Lew, and O. Stendahl. 1987. Cell surface expression of fMet-Leu-Phe receptors on human neutrophils. J. Clin. Invest. 79:1226-1233.

34. Fox, J. E. B., J. K. Boyles, C. C. Reynolds, and D. R. Phillips. 1984. Actin filament content and organization in unstimulated platelets. J. Cell Biol. 98:1985-1991.

35. Ohanian, V., L. C. Wolfe, K. W. John, V. C. Pinder, S. E. Lux, and W. B. Gratzer. 1984. Analysis of ternary interaction of the red cell membrane skeletal proteins, spectrin, actin and 4.1 Biochemistry. 23:4416-4420.

36. Coleman, T. R., A. S. Harris, S. M. Mische, M. S. Mooseker, and J. S. Morrow. 1987. Beta spectrin bestows protein 4.1 sensitivity on spectrin-actin interactions. J. Cell Biol. 104:519-526.

37. Eder, P. S., C.-J. Soong, and M. Tao. 1986. Phosphorylation reduces the affinity of protein 4.1 for spectrin. Biochemistry. 25:17641770.

38. Pasternak, G., R. A. Anderson, T. L. Leto, and V. T. Marchesi. 1985. Interactions between protein 4.1 and band $3:$ an alternative binding site for an element of the membrane skeleton. J. Biol. Chem. 260:3676-3683.

39. Anderson, R. A., and R. E. Lovrein. 1984. Glycophorin is linked by band 4.1 protein to the human erythrocyte membrane skeleton. Nature (Lond.). 307:655-658.

40. Anderson, R. A., and V. T. Marchesi. 1985. Regulation of the association of membrane skeletal protein 4.1 with glycophorin by a polyphosphoinositide. Nature (Lond.). 318:295-298.

41. Bourguignon, L. Y. W., S. J. Suchard, and E. L. Kalomiris 1986. Lymphoma Thy-1 glycoprotein is linked to the cytoskeleton via a 4.1-like protein. J. Cell Biol. 103:2529-2540.

42. Bourguignon, L. Y. W., S. J. Suchard, M. L. Nagpal, and J. R. Glenney, Jr. 1985. A T-lymphoma transmembrane glycoprotein (gp 180 ) is linked to the cytoskeletal protein, fodrin. J. Cell Biol. 101:477487.

43. Glenney, J. R., Jr., and P. Glenney. 1983. Fodrin is the general spectrin-like protein found in most cells whereas spectrin and the TW protein have a restricted distribution. Cell. 34:503-512.

44. Spiegel, J. E., D. S. Beardsley, F. S. Southwick, and S. E. Lux. 1984. An analogue of the erythroid membrane skeletal protein 4.1 in nonerythroid cells. J. Cell Biol. 99:886-893.

45. Perez, H. D., F. Elfman, E. Lobo, L. Sklar, D. Chenoweth, and C. Hooper. 1986. A derivative of wheat germ agglutinin specifically inhibits formyl-peptide-induced polymorphonuclear leukocyte chemotaxis by blocking re-expression (or recycling) of receptors. J. Immunol. 136:1803-1812.

46. Christiansen, N. P., and K. M. Skubitz. 1988. Identification of the major lectin-binding surface proteins of human neutrophils and alveolar macrophages. Blood. 71:1624-1632.

47. Perez, H. D., R. Ong, K. Khanna, D. Banda, and I. M. Goldstein. 1982. Wheat germ agglutinin specifically inhibits formyl peptide-induced polymorphonuclear leukocyte chemotaxis. J. Immunol. 129:2718-2724.

48. Perez, H. D., and R. R. Ong. 1984. Degranulation of polymorphonuclear leukocytes is induced by multivalent cross-linking of wheat germ agglutinin binding site(s) on cell membrane. Inflammation. 8:277-285.

49. O'Shea, J. J., E. J. Brown, T. A. Gaither, T. Takahashi, and M. M. Frank. 1985. Tumor-promoting phorbol esters induce rapid internalization of the $\mathrm{C} 3 \mathrm{~b}$ receptor via a cytoskeleton-dependent mechanism. J. Immunol. 135:1325-1330.

50. Vale, R. D., and E. M. Shooter. 1982. Alteration of binding properties and cytoskeletal attachment of nerve growth factor receptors in PC12 cells by wheat germ agglutinin. J. Cell Biol. 94:710-717.

51. Landreth, G. E., L. K. Williams, and C. McCutchen. 1985. Wheat germ agglutinin blocks the biological effects of nerve growth factor. J. Cell Biol. 101:1690-1694.

52. Sanchez-Madrid, F., J. A. Nagy, E. Robbins, P. Simon, and T. A. Springer. 1983. A human leukocyte differentiation antigen family with distinct $\alpha$-subunits and a common $\beta$-subunit. J. Exp. Med. 158:1785-1803.

53. Skubitz, K. M., Y.-S. Zhen, and J. T. August. 1983. A human granulocyte-specific antigen characterized by use of monoclonal antibodies. Blood. 61:19-26.

54. Stevenson, K. B., W. M. Nauseef, and R. A. Clark. 1987. The neutrophil glycoprotein $\mathrm{MO} 1$ is an integral membrane protein of plasma membranes and specific granules. J. Immunol. 139:37593763.

55. Clemetson, K. J., D. Bienz, M.-L. Zahno, and E. F. Luscher. 1984. Distribution of platelet glycoproteins and phosphoproteins in hydrophobic and hydrophilic phases in Triton X-114 phase partition. Biochim. Biophys. Acta. 778:463-469.

56. Tuan, T.-L., and F. Grinnell. 1988. Wheat-germ-agglutinin and Ricinus communis-agglutinin-binding sites of BHK cells compared with each other and with $140 \mathrm{kDa}$ fibronectin receptors. Biochem. $J$. 251:269-277.

57. Pytela, R., M. D. Pierschbacher, and E. Ruoslahti. 1985. Identification and isolation of a $140 \mathrm{kd}$ cell surface glycoprotein with properties expected of a fibronectin receptor. Cell. 40:191-198.

58. Brown, E. J., and J. L. Goodwin. 1987. The arg-gly-asp binding proteins of human monocytes (Mo) and polymorphonuclear leukocytes (PMN). J. Cell Biol. 105:46a. (Abstr.)

59. Mollinedo, F. 1986. Isolation of human neutrophil plasma membranes employing neutrophil cytoplasts and changes in the cellsurface proteins upon cell activation. Biochim. Biophys. Acta. 861:3343.

60. Bender, J. G., D. E. Van Epps, and D. E. Chenoweth. 1987. Independent regulation of human neutrophil chemotactic receptors after activation. J. Immunol. 139:3028-3033.

61. Crowley, C. A., J. T. Curnutte, R. E. Rosin, J. Andre-Schwartz, J. I. Gallin, M. Klempner, R. Snyderman, F. S. Southwick, T. P. Stossel, and B. M. Babior. 1980. An inherited abnormality of neutrophil adhesion. N. Engl. J. Med. 302:1163-1168.

62. Anderson, D. C., F. C. Schmalstieg, M. A. Arnaout, S. Kohl, M. F. Tosi, N. Dana, G. J. Buffone, B. J. Hughes, B. R. Brinkley, W. D. Dickey, J. S. Abramson, T. Springer, L. A. Boxer, J. M. Hollers, and C. W. Smith. 1984. Abnormalities of polymorphonuclear leukocyte function associated with a heritable deficiency of high molecular weight surface glycoproteins (GP 138): common relationship to diminished cell adherence. J. Clin. Invest. 74:536-551.

63. Arnaout, M. A., J. Pitt, H. J. Cohen, J. Melamed, F. S. Rosen, and H. R. Colten. 1982. Deficiency of a granulocyte-membrane glycoprotein (gp 150) in a boy with recurrent bacterial infections. $N$. Engl. J. Med. 306:693-699.

64. Rotrosen, D., and J. I. Gallin. 1987. Disorders of phagocyte function. Annu. Rev. Immunol. 5:127-150.

65. Dejana, E., S. Colella, L. R. Languino, G. Balconi, C. G. Corascio, and P. C. Marchisio. 1987. Fibrinogen induces adhesion, spreading, and microfilament organization of human endothelial cells in vitro. J. Cell Biol. 104:1403-1411.

66. Horwitz, A., K. Duggan, C. Buck, M. C. Beckerle, and K. Burridge. 1986. Interaction of plasma membrane fibronectin receptor with talin-a transmembrane linkage. Nature (Lond.). 320:531-533. 